\title{
DETERMINING FACTORS IN FOOD AWAY FROM HOME EXPENDITURE OF TURKISH HOUSEHOLDS
}

\author{
TERIN, M. \\ Department of Agricultural Economics, Faculty of Agriculture, Van Yuzuncu Yil University \\ 65080 Van, Turkey \\ e-mail: mustafaterin@yyu.edu.tr; phone: +90-432-225-1056 \\ (Received 22 $2^{\text {nd }}$ Jan 2019; accepted $14^{\text {th }}$ Feb 2019)
}

\begin{abstract}
The aim of this study was to determine the effects of socio-demographic and economic factors of households and household heads on monthly expenditures of food away from home (FAFH) in Turkey. The sample size was determined as 11290 households. The data were analyzed by generalized Heckman type sample selection models. The results showed that both the probability and monthly spending levels of household FAFH increased with male household heads, household income, whilst the married household heads, the households that receive cash income aids from the government and private sector, decreased both the probability and spending levels of FAFH in Turkey. The findings in the study may provide useful information for more effective identification and implementation of the marketing strategies of the stakeholders operating in the sector and also help the relevant public and private institutions determine more effective nutritional policies towards families with a certain profile.
\end{abstract}

Keywords: eating out, consumption, expenditure patterns, Heckman Sample Selection Model, Turkey

\section{Introduction}

Many countries have experienced changes in eating habits over the last decades in terms of individual consumers and households. These changes generally were from home consumption towards food away from home (Stewart et al., 2004; Akbay and Boz, 2005; Gül et al., 2007; Drescher and Roosen, 2013; Bozoglu et al., 2013; Niyonzima et al., 2017; Mottaleb et al., 2017). Changes were generally derived from convenience and increasing food availability, but demographic changes such as a higher share of working women and an increasing number of single households contributed as well (Nayga and Capps, 1992; Robson et al., 2016). One of the discouraging factors on the preparing the meal at home was reported to be working longer hours (Blick et al., 2017). In many studies, it was stated that globalization, urbanization, income, education, marketing, religion, culture, tourism women's participation in the labor force and consumer attitudes increases in FAFH consumption (Nayga, 1995; Ma et al., 2006; Bozoglu et al., 2013; Liu and Niyongira, 2017).

Worldwide, food consumption trends have been moving towards FAFH in many countries (Mancino et al., 2009; Bozoglu et al., 2013; Liu et al., 2013). For instance, the ratio of FAFH in household food expenditure of the United States of America (USA) increased twofold from $25 \%$ in 1954 to $50 \%$ in 2014 (USDA, 2018). This rate rose to $32 \%$ in 1992 in Canada (Jensen and Yen, 1996). FAFH ratio in 2002 was $24 \%$ reaching to $31 \%$ in 2008 in Brazil (Bezerra et al., 2013). In the last two decades, the percentage of FAFH rose to 25\% in 1996 and 30\% in 2006 in Spain (Mutlu and Gracia, 2006; Angulo et al., 2007). Again, the period of 2004-2010 experienced an increase from 20\% to 25\% FAFH consumption in Slovakia (Cupak et al., 2016), while in the 1987-1999 period FAFH consumption rate rose from $13 \%$ to $23 \%$ in Ireland (Keelan et al., 2009).

Turkey has also experienced similar changes in the pattern of food consumption expenditures mainly due to changes in the socio-economic structure of Turkish 
population in the last two decades. Composition and size of households, consumer lifestyles, per capita income, age distribution of the population and urbanization had a significant effect in FAFH. Thus, more efficient marketing strategies are required in the sector. Money spent of food, including non-alcoholic beverages as a share of total household spending continued to shrink, from $26.7 \%$ in 2002 to $19.5 \%$ in 2016, while expenditures on hotels, restaurants, and pastry shops (FAFH) as a share of total household spending increased from 4.4\% in 2002 to $6.4 \%$ in 2016 (TURKSTAT, 2018).

The current work has identified the effects of socio-demographic and economic factors of households and household heads on their FAFH consumption expenditures using a Double Hurdle (DH), Heckman Sample Selection (HSS) and Log-Heckman Sample Selection (LHSS) models. The study, which is rich in terms of household sociodemographic and economic profiles, also presented marginal impacts of exogenous variables on spending of FAFH. The presentation of such marginal effects may provide useful information for more effective identification and implementation of the marketing strategies of the stakeholders operating in the industry. This study will also help the relevant public and private institutions determine more effective nutritional policies towards families with a certain profile.

\section{Materials and methods}

Turkish Statistics Institute (TSI)' Household Budget Surveys data of 2015 was used as main material of this study. These data are regularly collected by TSI on the annual basis so as to cover the period between January 1 and December 31 and cover 10 thousand households on average across the country. The sample size was determined as 11290 family observations after deleting incomplete data and outliers.

Table 1 shows the descriptive statistics for sample. The results of this study showed that $77.3 \%$ of households had monthly expenditures on food away from home. In some studies conducted in different parts of Turkey, this ratio was reported as 55.4\% (Gül et al., 2007), 83.6\% (Uzunöz et al., 2011), 74.5\% (Bozoglu et al., 2013) and 68.4\% (Traş and Şengül, 2017). The reported figures for some countries, were as follows: Slovakia, 62.0\% (Cupak et al., 2016), Brazil, 40.0\% (Bezerra et al., 2013), China, 83.0\% (Liu et al., 2015), Egypt, 38\% (Fabiosa, 2008) and Malaysia, 71.9\% (Heng and Guan, 2007). Monthly average FAFH consumption expenditures of households were found to be 180.14 Turkish Liras (TL). These figures were as follows for different parts of Turkey: 137.66 TL (Bozoglu et al., 2013), 371.00 TL (Onurlubaş et al., 2015) and 131.82 TL (Traş and Şengül, 2017).

Three censored models competing with one another and at the same time compatible with the maximization of the utility function of consumers were considered. The mathematical representation of each econometric model were made here while referring to the textbooks on how these models are derived from the utility function under the good in question (e.g., food away from home). Before moving on to the presentation of each econometric model, it is worth mentioning a very important point here. Some families may not be able to consume FAFH and such observations are often reported as zero. Food away from home may not have been consumed, either because its current price is too high or because the family income is not affordable for the consumption or because of some health concerns and psychological factors. The Heckman sample selection (HSS) model is characterized by a selection equation $\left(\mathrm{d}_{\mathrm{i}}\right)$ (e.g., the decision on 
the expenditure of the food away from home) and level equation ( $\mathrm{y}_{\mathrm{i}}$ ) (e.g., monthly expenditure level for the food away from home) as follows (Eq. 1):

$$
\begin{aligned}
& \begin{array}{l}
d_{i}=1 \quad \text { if } \quad z_{i}^{\prime} \alpha+u_{1 i}>0 \\
\quad=0 \text { if } z_{i}^{\prime} \alpha+u_{1 i} \leq 0 \\
y_{i}=x_{i}^{\prime} \beta+u_{2 i} \quad \text { if } z_{i}^{\prime} \alpha+u_{1 i}>0 \\
\quad=0 \quad \text { if } z_{i}^{\prime} \alpha+u_{1 i} \leq 0
\end{array} \\
& \text { (can be =unobserved) if } z_{i}^{\prime} \alpha+u_{1 i} \leq 0
\end{aligned}
$$

where $\mathrm{z}$ and $\mathrm{x}$ are sets of exogenous factors affecting the household decision and expenditure levels on food away from home, respectively whilst $\alpha$ and $\beta$ are vectors of associative parameters to be estimated for each equation, respectively. $u_{1}$ and $u_{2}$ are error terms unknown to researchers. The error terms $\left(u_{1}, u_{2}\right)$ are distributed as truncated bivariate normal with zero means, standard deviations $(1, \sigma)$, correlation $\rho$, and covariance $\rho \sigma$, all indicating:

$$
\left[\begin{array}{l}
u_{1 i} \\
u_{2 i}
\end{array}\right] \square N\left(\left[\begin{array}{l}
0 \\
0
\end{array}\right],\left[\begin{array}{ll}
1 & \rho \sigma \\
\rho \sigma & \sigma^{2}
\end{array}\right]\right)
$$

The corresponding sample likelihood function is $(E q .2)$

$$
L=\prod_{d_{i}=0}\left\{1-\Phi\left(z_{i}^{\prime} \alpha\right)\right\} \prod_{d_{i}=1}\left\{\frac{1}{\sigma} \phi\left(\frac{y_{i}-x_{i}^{\prime} \beta}{\sigma}\right) \Phi\left(\frac{z_{i}^{\prime} \alpha+\frac{\rho}{\sigma}\left(y_{i}-x_{i}^{\prime} \beta\right)}{\left(1-\rho^{2}\right)^{1 / 2}}\right)^{-1}\right\}
$$

where $\Phi$ and $\phi$ are the univariate standard normal cumulative and probability distribution functions, respectively. The log-transformed Heckman SSM (LHSS) is characterized by replacing $\mathrm{y}_{\mathrm{i}}$ with $\log \mathrm{y}_{\mathrm{i}}$ in Equation 2 with its corresponding likelihood function as $(E q .3)$ :

$$
L=\prod_{d_{i}=0}\left\{1-\Phi\left(z_{i}^{\prime} \alpha\right)\right\} \prod_{d_{i}=1}\left\{y_{i}^{-1} \frac{1}{\sigma} \phi\left(\frac{\log y_{i}-x_{i}^{\prime} \beta}{\sigma}\right) \Phi\left(\frac{z_{i}^{\prime} \alpha+\frac{\rho}{\sigma}\left(\log y_{i}-x_{i}^{\prime} \beta\right)}{\left(1-\rho^{2}\right)^{1 / 2}}\right)^{-1}\right\}
$$

The same distributional assumption for error terms $\left(u_{1}, u_{2}\right)$ as in Heckman-SSM are maintained and $y_{i}^{-1}$ is the Jacobian of transformation from $\log y_{i}$ to $y_{i}$. Now, augmenting the binary decision $z_{i}^{\prime} \alpha+u_{1 i}$ with an additional mechanism $x_{i}^{\prime} \alpha+u_{2 i}$ the double-hurdle (DH) model can be stated as follows (Eq. 4): 


$$
\begin{array}{cccc}
y_{i} & =x_{i}^{\prime} \beta+u_{2 i} & \text { if } & z_{i}^{\prime} \alpha+u_{1 i}>0 \text { and } x_{i}^{\prime} \beta+u_{2 i}>0 \\
& =0 & \text { if } & z_{i}^{\prime} \alpha+u_{1 i} \leq 0 \text { and } x_{i}^{\prime} \beta+u_{2 i} \leq 0
\end{array}
$$

The error terms $\left(u_{1}, u_{2}\right)$ in the double-hurdle model are distributed as the bivariate normal as in Heckman's (1979) sample selection model (HSS) without truncation. The sample likelihood function is (Eq. 5):

$$
L=\prod_{d_{i}=0}\left\{1-\Phi_{2}\left(z_{i}^{\prime} \alpha, \frac{x_{i}^{\prime} \beta}{\sigma}, \rho\right)\right\} \prod_{d_{i}=1}\left\{\frac{1}{\sigma} \phi\left(\frac{y_{i}-x_{i}^{\prime} \beta}{\sigma}\right) \Phi\left(\frac{z_{i}^{\prime} \alpha+\frac{\rho}{\sigma}\left(y_{i}-x_{i}^{\prime} \beta\right)}{\left(1-\rho^{2}\right)^{1 / 2}}\right)\right\}
$$

where $\Phi 2$ is the standard bivariate cumulative distribution function. By imposing parametric restriction $\rho=0$ in model, The HSS, LHSS and DH models reduce to their two-part models. This can be done via the conventional tests such as Wald, Likelihood Ratio, or Lagrangian Multiplier (LM). On the other hand, the choice between the three competing models can be done by a non-nested Vuong's specification test.

While the probability of both the HSS and LHSS models are the same, their conditional and unconditional, expenditure level equations vary greatly (Eq. 6):

$$
\operatorname{Pr}\left(y_{i}>0\right)=\Phi\left(z_{i}^{\prime} \alpha\right)
$$

Conditional and unconditional means of $\mathrm{y}_{\mathrm{i}}$ of the HSS model are respectively $(E q .7)$ :

$$
E\left(y_{i} \mid d_{i}=1\right)=x_{i}^{\prime} \beta+\rho \sigma \frac{\phi\left(z_{i}^{\prime} \alpha\right)}{\Phi\left(z_{i}^{\prime} \alpha\right)} \text { and } E\left(y_{i} \mid d_{i}=1\right)=\Phi\left(z_{i}^{\prime} \alpha\right) x_{i}^{\prime} \beta+\rho \sigma \phi\left(z_{i}^{\prime} \alpha\right)
$$

While the conditional and unconditional mean levels for the LHSS model is respectively $(E q .8)$ :

$$
E\left(y_{i} \mid d_{i}=1\right)=\exp \left(x_{i}^{\prime} \beta+\sigma^{2} / 2\right) \frac{\Phi\left(z_{i}^{\prime} \alpha+\rho \sigma\right)}{\Phi\left(z_{i}^{\prime} \alpha\right)} \text { and } E\left(y_{i} \mid d_{i}=1\right)=\exp \left(x_{i}^{\prime} \beta+\sigma^{2} / 2\right) \Phi\left(z_{i}^{\prime} \alpha+\rho \sigma\right)
$$

However, the probability, conditional and unconditional mean levels of monthly household food away from home product in DH is, respectively (Eq. 9):

$$
\begin{aligned}
& \operatorname{Pr}\left(y_{i}>0\right)=\Phi_{2}\left(z_{i}^{\prime} \alpha, \frac{x_{i}^{\prime} \beta}{\sigma} ; \rho\right) \\
& E\left(y_{i} \mid y_{i}>0\right)=x_{i}^{\prime} \beta+\sigma \Phi_{2}\left(z_{i}^{\prime} \alpha, \frac{x_{i}^{\prime} \beta}{\sigma} ; \rho\right)^{-1}\left\{\phi\left(\frac{x_{i}^{\prime} \beta}{\sigma}\right) \Phi\left[\frac{z_{z}^{\prime} \alpha-\rho x_{i}^{\prime} \beta / \sigma}{\sqrt{1-\rho^{2}}}\right]+\rho \phi\left(z_{i}^{\prime} \alpha\right) \Phi\left[\frac{x_{i}^{\prime} \beta / \sigma-\rho z_{i}^{\prime} \alpha}{\sqrt{1-\rho^{2}}}\right]\right\} \\
& E\left(y_{i}\right)=\operatorname{Pr}\left(y_{i}>0\right) E\left(y_{i} \mid y_{i}>0\right)
\end{aligned}
$$

Marginal effects can be obtained by differentiation each equation with respect to $\mathrm{z}$ and $x$ variables. Delta method is used to construct the variance-covariance of marginal impact estimates. 
Table 1. Variable definition and sample means

\begin{tabular}{|c|c|c|c|}
\hline Variables & Definition & Mean & VIF \\
\hline \multicolumn{4}{|c|}{ Dependent variables } \\
\hline \multirow{2}{*}{ Food away from home } & Expenses per month (TL) & $180.14(235.58)$ & - \\
\hline & $\%$ consuming & $77.3 \%$ & - \\
\hline \multicolumn{4}{|c|}{ Independent variables } \\
\hline \multicolumn{4}{|c|}{ Continuous explanatory variables } \\
\hline Children 0-5 & Number of kids aged $0-5$ & $0.316(0.637)$ & - \\
\hline Children 6-14 & Number of kids aged 6-14 & $0.569(0.917)$ & - \\
\hline Children $15-18$ & Number of kids aged $15-18$ & $0.215(0.481)$ & - \\
\hline Adult $19+$ & Number of adults aged over 18 years & $2.476(1.085)$ & - \\
\hline Total expenditure & Household total expenditure (1000 TL/month) & $2.782(2.047)$ & - \\
\hline Household size & Household size & $3.576(1.900)$ & 1.758 \\
\hline Education & Household head education in years & $7.392(4.801)$ & 1.913 \\
\hline House feature index & Index created by house characteristics & $7.270(2.236)$ & 2.499 \\
\hline Number of autos & Number of automobiles owned & $0.449(0.497)$ & 1.272 \\
\hline Number of properties & Number of properties owned & $1.025(1.156)$ & - \\
\hline \multicolumn{4}{|c|}{$\begin{array}{c}\text { Binary explanatory variables: } \\
\text { Household head and household characteristics }\end{array}$} \\
\hline Male & Gender is male & $0.862(0.345)$ & 2.223 \\
\hline Age $<30$ & Age $<30$ (Reference) & $0.076(0.265)$ & - \\
\hline Age $30-50$ & $30<$ Age $\leq 50$ & $0.457(0.498)$ & 4.213 \\
\hline Age $>50$ & Age $>50$ & $0.467(0.499)$ & 5.399 \\
\hline No diploma & No diploma (Reference) & $0.128(0.330)$ & - \\
\hline Primary school & Primary school education & $0.445(0.497)$ & - \\
\hline Secondary school & Secondary school education & $0.122(0.328)$ & - \\
\hline High school & High school education & $0.163(0.370)$ & - \\
\hline College school & College school education & $0.142(0.349)$ & - \\
\hline Compulsory insurance & Has compulsory health insurance & $0.840(0.367)$ & 1.517 \\
\hline Married & Married & $0.835(0.371)$ & 2.298 \\
\hline Employed & Employed & $0.666(0.472)$ & 1.926 \\
\hline Manager & Manager & $0.047(0.211)$ & 1.110 \\
\hline Retired & Retired & $0.320(0.467)$ & 2.072 \\
\hline Entrepreneurial income & Families with entrepreneurial income & $0.339(0.473)$ & 1.432 \\
\hline State cash aids & Receives cash income from government & $0.304(0.460)$ & 1.484 \\
\hline State in-kind aids & Receives in-kind type help income from state & $0.105(0.307)$ & 1.306 \\
\hline Private cash aids & Receives cash income from private & $0.131(0.337)$ & 1.185 \\
\hline Private in-kind aids & Receives in-kind type income from private & $0.096(0.295)$ & 1.170 \\
\hline Foreign income & Has abroad retired, scholarship or in-kind aid & $0.024(0.152)$ & 1.033 \\
\hline Apartment & Resides in an apartment & $0.493(0.500)$ & 2.096 \\
\hline Renter & Resides in rental house & $0.230(0.421)$ & 2.187 \\
\hline Homeowner & Resides in own house & $0.632(0.482)$ & 2.248 \\
\hline Combi & Resides in a house warmed up with a combi & $0.321(0.467)$ & 2.435 \\
\hline Stove & Resides in a house warmed up with a stove & $0.547(0.498)$ & 3.736 \\
\hline Income 1 & Monthly income < 2000 TL (Reference) & $0.374(0.484)$ & - \\
\hline Income 2 & Monthly income $2000-5000$ TL & $0.494(0.500)$ & 1.725 \\
\hline Income 3 & Monthly income > $5000 \mathrm{TL}$ & $0.132(0.338)$ & 2.019 \\
\hline Internet & Has home internet access & $0.350(0.477)$ & 1.442 \\
\hline One child & Family with only one children & $0.195(0.396)$ & 1.358 \\
\hline Two child & Family with only two children & $0.197(0.398)$ & 1.529 \\
\hline Three and more child & Family with three and more children & $0.141(0.348)$ & 1.611 \\
\hline \multicolumn{2}{|l|}{ Sample size } & 11290 & \\
\hline
\end{tabular}

Standard deviations are in parentheses 


\section{Results and discussion}

\section{Specification tests and maximum-likelihood estimates}

Before discussing the marginal impacts of the preferred model, some specifications applied to the data and models were taken into consideration. First, in each model under consideration, the two-part models were rejected using Wald statistic $\left(\mathrm{W}=\frac{\rho^{2}}{\operatorname{Var}(\rho)}\right.$, df $=1$, where $\operatorname{Var}(\rho)$ is the estimated variance of the correlation coefficient, $\rho$, between the decision to participate at food-away from home and its expenditure level). Therefore, the error terms generating the relationship between the decision to spend and the spending levels on FAFH are statistically interrelated, affecting one to other equations. In addition, Vuong non-nested tests discriminating competed models were used (see Table 2). In all pair comparison, the error-dependent log-Heckman sample selection (LHSS) model outperforms over its competitors (e.g., the double-hurdle and conventional error-dependent Heckman models). Most likely, the logarithmic nature of the model correcting outliers and minimizing the persistent heteroscedasticity in the data gives an advantage to the LHSS model to outperform the other two competing models (e.g., HSS and DH). In this case, all correlation coefficients are statistically significant, indicating after controlling exogenous variables in models, uncontrollable factors that affect the decision to spend also significantly affect the spending level on FAFH. The correlation coefficient in the LHSS model is negative, indicating that the uncontrollable factors that boost the likelihood to spend also reduce expenditure level or vice-versa. Also sings of most of the estimated parameters echoed with the economic theory. Since these parameters do not indicate the direct marginal effects of regressors on both the probability and the spending level, the marginal impacts derived from Equations 6-9 were discussed in subsequent section.

Table 2. Some specification tests comparing independence and used models

\begin{tabular}{c|c}
\hline Specification tests & Test-statistic \\
\hline Independence & \\
\hline Heckman SS & Wald 491.3661, df $=1, \mathrm{p}<0.0001$ \\
Log-Heckman SS & Wald 1009.967, df $=1, \mathrm{p}<0.0001$ \\
Double- hurdle & Wald 196.0345, df $=1, \mathrm{p}<0.0001$ \\
\hline Vuong's non-nested test & $z=54.3073, \mathrm{p}<0.0001$ \\
\hline Double-hurdle versus Heckman SS & $z=-14.0318, \mathrm{p}<0.0001$ \\
Double-hurdle versus Log-Heckman SS & $z=-30.2837, \mathrm{p}<0.0001$ \\
\hline Heckman SS versus Log-Heckman SS & \\
\hline
\end{tabular}

Note: The null hypothesis under Vuong's test for non-nested models is that the expected value of competing log-likelihood ratios equals zero, indicating the competing pair models are equally away from the data being modelled. Under this test, if $\mathrm{z}>1.96$ the first listed model is preferred, while if $\mathrm{z}<-$ 1.96 the second listed model is chosen. However, if $|\mathrm{z}|<1.96$ then no decision is made among the competing pairs

\section{Marginal effects}

Marginal effects of explanatory variables on the probabilities, conditional level, and unconditional level of FAFH households are presented at Table 3. According to these results, it was observed that various socio-demographic and economic factors of 
households and heads of households had significant effects on FAFH expenditures. The subsequent discussion will continue only on statistically significant variables for the preferred LHSS model.

Table 3. The error-dependent Log-Heckman sample selection (LHSS) model both with maximum likelihood (MLE) and marginal impact estimates

\begin{tabular}{|c|c|c|c|c|c|c|c|c|c|c|}
\hline \multirow{3}{*}{ Variables } & \multicolumn{4}{|c|}{ MLE estimates } & \multicolumn{6}{|c|}{ Marginal effects } \\
\hline & \multicolumn{2}{|c|}{ Probability } & \multicolumn{2}{|c|}{ Level } & \multicolumn{2}{|c|}{ Probability } & \multicolumn{2}{|c|}{ Conditional } & \multicolumn{2}{|c|}{ Unconditional } \\
\hline & Parameter & t-value & Parameter & t-value & Parameter & t-value & Parameter & t-value & Parameter & t-value \\
\hline Constant & -0.164 & -1.337 & $4.837^{* * * *}$ & 34.399 & & & & & & \\
\hline Male & $0.280^{* * *}$ & 5.099 & -0.092 & -1.392 & $8.321^{\text {**** }}$ & 4.750 & $25.179^{* * * *}$ & 3.002 & $34.390^{* * * *}$ & 4.792 \\
\hline Age $30-50$ & -0.019 & -0.279 & $-0.163^{* *}$ & -2.373 & -0.512 & -0.278 & $-33.116^{\text {**** }}$ & -2.623 & $-27.676^{* *}$ & -2.324 \\
\hline Age $>50$ & $-0.309^{* * *}$ & -4.303 & -0.060 & -0.798 & $-8.495^{* * *}$ & -4.275 & $-27.042^{* * *}$ & -4.255 & $-61.628^{* * *}$ & -4.919 \\
\hline Married & $-0.199^{* * * *}$ & -3.723 & $-0.249^{* * *}$ & -4.036 & $-5.124^{* * *}$ & -3.967 & $-87.301^{* * *}$ & -7.193 & $-83.125^{* * *}$ & -7.658 \\
\hline Employed & $0.218^{* * *}$ & 5.769 & $0.345^{* * *}$ & 7.728 & $6.164^{* * *}$ & 5.649 & $90.769^{* * * *}$ & 13.853 & $83.169^{* * * *}$ & 14.237 \\
\hline Manager & -0.121 & -1.643 & 0.018 & 0.223 & -3.476 & -1.574 & -14.686 & -1.091 & -17912 & -1.456 \\
\hline $\begin{array}{l}\text { Compulsory } \\
\text { insurance }\end{array}$ & $0.131^{* * *}$ & 3.271 & $0.203^{* * *}$ & 4.207 & $3.712^{* * *}$ & 3.160 & $-52.520^{* * *}$ & -8.458 & $48.052^{* * *}$ & 8.864 \\
\hline Retired & $0.090^{* *}$ & 2.262 & $-0.346^{* * *}$ & -7.359 & $2.437^{* *}$ & 2.290 & $-49.084^{* * *}$ & -6.922 & $-35.426^{* * * *}$ & -5.575 \\
\hline $\begin{array}{l}\text { Entrepreneurial } \\
\text { income }\end{array}$ & $-0.132^{* * *}$ & -3.809 & $-0.473^{* * *}$ & -11.867 & $-3.680^{* * *}$ & -3.769 & $-100.33^{* * *}$ & -16.24 & $-86.892^{* * *}$ & -15.64 \\
\hline State cash aids & $-0.120^{* * *}$ & -3.670 & $-0.258^{* * *}$ & -6.586 & $-3.358^{* * *}$ & -3.604 & $-62.514^{* * * *}$ & -11.27 & $-55.990^{* * * *}$ & -11.44 \\
\hline $\begin{array}{l}\text { State in-kind } \\
\text { aids }\end{array}$ & -0.029 & -0.671 & -0.003 & -0.052 & -0.789 & -0.665 & -4.781 & -0.609 & -5.309 & -0.784 \\
\hline $\begin{array}{l}\text { Private cash } \\
\text { aids }\end{array}$ & 0.064 & 1.479 & $-0166^{* * *}$ & 3.342 & 1.724 & 1.511 & $-20.759^{* * *}$ & -2.858 & $-13.780^{* *}$ & -2.102 \\
\hline $\begin{array}{l}\text { Private in-kind } \\
\text { aids }\end{array}$ & 0.012 & 0.249 & -0.024 & -0.431 & 0.322 & 0.250 & -2.700 & -0.315 & -15.582 & -0.207 \\
\hline Foreign income & 0.042 & 0.523 & $-0.166^{*}$ & -1.709 & 1.121 & 0.532 & $-23.497^{*}$ & -1.762 & -17.111 & -1.456 \\
\hline Apartment & -0.064 & -1.553 & -0.064 & -1.425 & -1.762 & 1.553 & $-21.647^{* * *}$ & -2.840 & $-20.775^{* * *}$ & -2.948 \\
\hline Renter & $0.109^{* *}$ & 2.089 & 0.053 & 0.943 & $2.926^{* *}$ & 2.144 & $27.248^{* * *}$ & 2.602 & $27.914^{* * *}$ & 2.860 \\
\hline Homeowner & $-0.110^{* *}$ & -2.338 & 0.014 & 0.280 & $-2.969^{* *}$ & -2.370 & -13.912 & -1.608 & $-16.905^{* *}$ & -2.096 \\
\hline Combi & -0.033 & -0.646 & 0.038 & 0.689 & -0.898 & -0.643 & 2.210 & 0.225 & 0.091 & 0.010 \\
\hline Stove & 0.048 & 0.888 & -0.045 & -0.752 & 1.322 & 0.887 & -1.231 & 0.124 & 1.488 & 0.163 \\
\hline Internet & $0.107^{* * *}$ & 2.787 & $0.094^{* *}$ & 2.328 & $2.897^{* * * *}$ & 2.839 & $34.529^{* * *}$ & 4.345 & $33.612^{* * * *}$ & 4.478 \\
\hline One child & $0.222^{* * * *}$ & 5.279 & $0.093^{* *}$ & 2.017 & $5.719^{* * * *}$ & 5.657 & $54.084^{* * * *}$ & 5.791 & $56.268^{* * * *}$ & 6.452 \\
\hline Two child & $0.167^{* * *}$ & 3.785 & 0.018 & 0.371 & $4.370^{* * * *}$ & 3.968 & $29.211^{* * *}$ & 3.271 & $32.543^{* * * *}$ & 3.928 \\
\hline $\begin{array}{c}\text { Three and more } \\
\text { child }\end{array}$ & 0.057 & 1.207 & -0.016 & -0.302 & 1.538 & 1.229 & 5.511 & 0.600 & 7.396 & 0.886 \\
\hline $\begin{array}{l}\text { House feature } \\
\text { index }\end{array}$ & -0.012 & -1.254 & 0.003 & 0.283 & -0.331 & 1.254 & -1.227 & -0.649 & -1.611 & -0.939 \\
\hline $\begin{array}{c}\text { Number of } \\
\text { autos }\end{array}$ & 0.041 & 1.331 & $-0.085^{* *}$ & -2.401 & 1.116 & 1.333 & $-9.708^{*}$ & -1.709 & -5.751 & -1.122 \\
\hline Primary school & $0.198^{* * *}$ & 5.719 & & & $5.360^{* * * *}$ & 5.743 & $29.807^{* * *}$ & 5.632 & $34.272^{* * * *}$ & 5.653 \\
\hline $\begin{array}{c}\text { Secondary } \\
\text { school }\end{array}$ & $0.206^{* * *}$ & 4.190 & & & $5.249^{* * *}$ & 4.499 & $31.791^{* * *}$ & 4.052 & $36.759^{* * *}$ & 4.045 \\
\hline High school & $0.306^{* * *}$ & 5.391 & & & $7.625^{* * *}$ & 5.969 & $47.668^{* * *}$ & 5.144 & $55.183^{* * *}$ & 5.143 \\
\hline College school & $0.209^{* * *}$ & 3.027 & & & $5.357^{* * * *}$ & 3.262 & $32.333^{* * *}$ & 2.933 & $37.377^{* * * *}$ & 2.925 \\
\hline $\begin{array}{l}\text { Number of } \\
\text { properties }\end{array}$ & $-0.041^{* * * *}$ & -3.217 & & & $-1.112^{* * *}$ & -3.215 & $-6.100^{* * *}$ & -3.202 & $-7.009^{* * *}$ & -3.206 \\
\hline Children 0-5 & $-0.105^{* * *}$ & -5.135 & & & $-2.882^{* * *}$ & -5.119 & $-15.813^{* * *}$ & -5.107 & $-18.170^{* * * *}$ & -5.117 \\
\hline Children 6-14 & $-0.077^{* * * *}$ & -5.132 & & & $-2.094^{* * *}$ & -5.133 & $-11.492^{* * * *}$ & -5.097 & $-13.205^{* * *}$ & -5.103 \\
\hline Children 15-18 & 0.029 & 1.200 & & & 0.797 & 1.199 & 4.374 & 1.199 & 5.026 & 1.200 \\
\hline Adult $19+$ & $0.088^{* * *}$ & 7.304 & & & $2.400^{* * * *}$ & 7.243 & $13.169^{* * *}$ & 7.228 & $15.132^{* * * *}$ & 7.257 \\
\hline $\begin{array}{c}\text { Total } \\
\text { expenditures }\end{array}$ & $0.221^{* * *}$ & 27.238 & & & $6.038^{* * *}$ & 26.295 & $33.137^{* * * *}$ & 20.347 & $38.076^{* * * *}$ & 21.590 \\
\hline Education & & & $-0.025^{* * *}$ & -5.404 & & & $-4.657^{* * * *}$ & -5.323 & $-3.758^{* * *}$ & -5.321 \\
\hline Household size & & & $0.103^{* * *}$ & 11.157 & & & $19.391^{* * * *}$ & 10.821 & $15.650^{* * *}$ & 10.762 \\
\hline Income 2 & & & $0.477^{* * *}$ & 14.476 & & & $90.648^{* * *}$ & 13.336 & $73.161^{* * * *}$ & 13.238 \\
\hline Income 3 & & & $0.062^{* * *}$ & 14.056 & & & $233.042^{* * *}$ & 9.705 & $188.085^{* * *}$ & 9.655 \\
\hline$\sigma$ & & & $1.532^{* * *}$ & 105.393 & & & & & & \\
\hline$\rho$ & & & $-0.982^{* * * *}$ & -96.855 & & & & & & \\
\hline kelihood & & & & & & & & & & \\
\hline
\end{tabular}

Statistical significance $* * *$ at the $1 \%$ level; ** at the $5 \%$ level; * at the $10 \%$ level 
Because of culinary skills, households under the supervision of the male are reported to have higher FAFH expenditures (Byrne et al., 1996). Our results confirmed that hypothesis. Households with a male headed were $8.32 \%$ more likely to consume FAFH and spend 25.18 TL more per month than households with a female headed Bozoglu et al. (2013) found that male household heads tended to $13.84 \%$ more likely to consume FAFH and spend 51.05 TL more per month than their female peers. Previous findings is consistent with our findings (Byrne et al., 1996; Ham et al., 2004; Binkley, 2006; Angulo et al., 2007; Keelan et al., 2009; Fanning et al., 2010; Liu et al., 2013; Blick et al., 2017).

Heng and Guan (2007) reported that the young differed from the old as regards tastes, food preferences, lifestyle, eating habits and opportunities to socialize. In the study, there was a negative relationship between the age of the head of household and the monthly average expenditure on FAFH. Household with households heads whose ages between $30-50$ and over 50 years tended $0.51 \%$ and $8.50 \%$ points less likely to consume FAFH and they spent 33.12 TL and 27.04 TL less than households whose heads aged below 30 years. These negative effects of ages were also reported in previous studies conducted in Turkey (Akbay et al., 2007; Gül et al., 2007), in South Africa (Blick et al., 2017), in China (Min et al., 2004; Ma et al., 2006), in USA (Stewart and Yen, 2004; Binkley, 2006), in Ireland (Keelan et al., 2009), in Slovakia (Cupak et al., 2016), in Egypt (Fabiosa, 2008), in Brazil (Rezende and Avelar, 2012), and in Spain (Mutlu and Gracia, 2006; Angulo et al., 2007).

Households with a married head were $5.12 \%$ points less likely to consume FAFH and spent $87.30 \mathrm{TL}$ less per month than single headed households. The results indicated that married households were less likely to consume FAFH and spent less than single headed households. Bozoglu et al. (2013) found that married household heads tended to $4.14 \%$ points less likely to consume FAFH and spent $18.60 \mathrm{TL}$ less per month than that of unmarried peers. Our results were consistent with the earlier findings (Ham et al., 2004; Keelan et al., 2009; Drescher and Roosen, 2013; Piekut, 2016; Traş and Şengül, 2017).

Compulsory health insurance played a positive role in the probability of consume FAFH, but negatively affected the expenditure levels. Households whose heads had a compulsory health insurance were $3.71 \%$ points more likely to consume FAFH but spent 52.52 TL less per month than those without insurance. Employment played a role on FAFH, households with an employed head were $6.16 \%$ points more likely to consume FAFH and spent 90.77 TL more per month than their unemployed counterparts. The findings showed that households with employed head in Turkey had significantly higher probability of entering the FAFH market and they spent more on FAFH. Bozoglu et al. (2013) and Traş and Şengül (2017) reported a positive employment effect on FAFH in Turkey. These positive effects of employment were also reported for USA (Jensen and Yen, 1996; Stewart and Yen, 2004), for Spain (Angulo et al., 2007), for Mexico (Langellier, 2015) and for Slovakia (Cupak et al., 2016).

Households with a retired head were $2.43 \%$ points more likely to consume FAFH but spent $49.08 \mathrm{TL}$ less per month than their not retired counterparts. Retired played a positive role in the probability of consume on FAFH, but negatively affected expenditure levels. These results were in line with the expectations because retired household head, on average might be older than those not retired and similar health and/or financial reasons in the retired group might result in less consumption of FAFH. Piekut (2016) found that in Poland, households with a retired head were less likely to 
consume FAFH and spent 15.96 PLN per month than those not retired households head. Negative effects of retired household head on FAFH were also reported in earlier studies (Jang et al., 2007; Drescher and Roosen, 2013).

In the study, the households receiving financial aid from the state resources had lower probability of consumption and related expenditure levels by $3.39 \%$ points and 62.51 TL, respectively, in comparison to those who were not receiving financial aid from public resources. This finding was in line with findings of Binkley (2006). The finding was in accordance of expectations. The major reason could be income levels and high quality life due to financial support provided by the government. Therefore, it is expected that the expenditures on such households on FAHF would be lower.

Households residing in rental house were $2.93 \%$ more likely to consume FAFH and spent 27.25 TL more per month than those residing state apartments. This result was consistent with Bozoglu et al. (2013), who reported a positive relationship between households residing in rental house and FAFH expenditures. Home ownerships had a higher income compared to no home ownership due to high income and low cash flow effects, which is contradictory, the effects of homeowner status on FAFH is reported to be unclear (Yen, 1993). This means that homeowner would show a less probability of FAFH and less expenditure on FAFH in comparison of hypothesized a lack of homeowner. Homeowners were $2.97 \%$ points less likely to consume FAFH and spent 16.91 TL less per month than those residing state apartments, similar to findings by Ham et al. (2004), but contradicts to those by Jensen and Yen (1996), Mutlu and Gracia (2006), Jang et al. (2007) and Keelan et al. (2009).

Having an internet connection at home increased the probability of consuming FAFH (2.90\%) and it also had a significant and positive effect on FAFH expenditures for households (34.53 TL). This result was consistent with Bozoglu et al. (2013) who reported a positive relationship between having an Internet connection at home and FAFH expenditures.

Households with only one and two children were $5.72 \%$ and $4.37 \%$ points more likely to consume FAFH and spend 54.08 TL and 29.21 TL more per month than households without children, respectively. These results agreed with the expectations. Piekut (2016) found that in Poland, households with a children are more likely to consume FAFH and spent 16.49 PLN per month than childless households. Similar findings were also reported by Stewart and Yen (2004) and Bozoglu et al. (2013).

Education level increases the probability of the FAFH decision and also increases expenditures on FAFH. Households with a primary, secondary, high and college school head were $5.36 \%, 5.25 \%, 7.63 \%$ and $5.36 \%$ points more likely to consume FAFH, and spent 29.81 TL, 31.79 TL, 47.67 TL and 32.33 TL more per month than their illiterate counterparts, respectively. The findings were consistent with the previous findings (Jensen and Yen, 1996; Mihalopoulos and Demoussis, 2001; Stewart and Yen, 2004; Angulo et al., 2007; Zan and Fan, 2010; Langellier, 2015; Cupak et al., 2016; Piekut, 2016; Traş and Şengül, 2017).

Households who had pre-school children is reported to have spent less FAFH expenditures compared to other families mainly because of difficulties feeding children in public places (Heng and Guan, 2007). Our results confirmed this expectation. In the study, households with a young children aged $0-5$ and aged $6-14$ were $2.88 \%$ and $2.09 \%$ less likely to consume FAFH and they spent $15.81 \mathrm{TL}$ and 11.49 TL less than their counterparts without such young children, respectively. Presence of children (aged 0-5 and aged 6-14) decreased FAFH expenditure of households. Negative effects of 
pre-school (aged 0-5) and school children (aged 6-14) on FAFH were also reported in the earlier studies (Mihalopoulos and Demoussis, 2001; Keelan et al., 2009; Chang and Yen, 2010; Drescher and Roosen, 2013; Leschewski et al., 2018; Rezende and Avelar, 2012).

As the total expenditure of households increased, the probability of consuming FAFH increased by $6.04 \%$ points and spending increased by 33.14 TL per month. These positive effects of total expenditure might be related to the increased income because household's total expenditures are generally viewed as proxy for income. The positive effects of total expenditure of households on FAFH expenditures were consistent with the earlier studies (Mihalopoulos and Demoussis, 2001; Fabiosa, 2008; Traş and Şengül, 2017).

Level of FAFH expenditure and the probability of consumption in the FAFH market were affected positively from household size. Each additional household member increased the probability of consuming FAFH by $0.10 \%$ point, the conditional expenditure by 19.39 TL per month. While these positive effects of household size on FAFH was in consistent with the findings of some earlier studies (Mihalopoulos and Demoussis, 2001; Ham et al., 2004; Chang and Yen, 2010; Cupak et al., 2016), it contradicted with some other findings of Stewart and Yen (2004), Heng and Guan (2007), Akbay et al. (2007), Drescher and Roosen (2013) and Mottaleb et al. (2017).

Households with an average monthly income between 2000 and 5000 TL and over 5000 TL spent 90.65 TL on FAFH and 233.04 TL more than households with an average monthly income below 2000 TL. This was consistent with the applied theoretical framework and other empirical studies investigating the link between income and FAFH spending (Byrne et al., 1996; Min et al., 2004; Ma et al., 2006; Zan and Fan, 2010; Liu et al., 2013; Cupak et al., 20016; Piekut, 2016; Blick et al., 2017; Traş and Şengül, 2017). The results were as it is expected. The major reasons could be households with relatively high income would tend to have more expenditure on products and services including dinning (Bozoglu et al., 2013).

\section{Conclusions}

In the study, the characteristics of households and the heads of households had a significant effect on determining the probability of consuming FAFH and the related expenditure. The findings were supported by analyses. Results showed that $77.3 \%$ of Turkish households participated in the FAFH market.

The results also showed that both the probability and monthly spending levels of household FAFH increased with male household heads, decreasing in age of household heads, educational levels of household heads, working household heads, household size, household income, reside in rental house, use of internet and the number of adults in a family, whilst the female headed households, married household heads, the households receiving cash income aids from the government and private sector, homeowner, the number of properties in family and families with children 0-5 and 6-14 years old, decreased both the likelihood and spending levels of food away from home in Turkey.

These findings are very important especially for the companies and enterprises operating in the non-home food industry. Because knowing the factors that increase and decrease the food consumption expenditures of households FAFH will provide important clues to the companies and enterprises operating in this sector for what kind of services they will develop for households. For example, children's play areas for 
households with children, car parking for car-owners, low-income households and large households multiple alternative options will have a positive impact on household consumption expenditures. Increasing demand for FAFH will probably ensure further growth in industry. In these days, industry provides employment for many people and creates demand for other food chains from farmers to retailers.

\section{REFERENCES}

[1] Akbay, C., Boz, I. (2005): Economic analysis of food at home and food away from home consumption and consumer behavior in Kahramanmaraş. - KSU Journal of Science and Engineering 8: 122-131.

[2] Akbay, C., Tiryaki, G. Y., Gül, A. (2007): Consumer characteristics influencing fast food consumption in Turkey. - Food Control 18: 904-913.

[3] Angulo, A. M., Gil, J. M., Mur, J. (2007): Spanish demand for food away from home: Analysis of panel data. - Journal of Agricultural Economics 58: 289-307.

[4] Bezerra, I. N., Souza, A. M., Pereira, R. A., Sichieri, R. (2013): Consumption of foods away from home in Brazil. - Rev Saude Publica 41: 200-211.

[5] Binkly, J. K. (2006): The effect of demographic, economic, and nutrition factors on the frequency of food away from home. - The Journal of Consumer Affairs 40: 372-391.

[6] Blick, M., Abidoye, B. O., Kirsten, J. F. (2017): An investigation into food-away-fromhome consumption in South Africa. - Development Southern Africa 35: 1-14.

[7] Bozoglu, M., Bilgic, A., Yen, S. Y., Huang, C. L. (2013): Household food expenditures at home and away from home in Turkey. - Paper presented at the annual meeting for Agricultural \& Applied Economics Association, August 4-6.

[8] Byrne, P. J., Capps, O., Saha, A. (1996): Analysis of food-away-from-home expenditure patterns for U. S. Households 1982-89. - American Journal of Agricultural Economics 78: 614-627.

[9] Chang, H. H., Yen, S. T. (2010): Off-farm employment and food expenditures at home and away from home. - European Review of Agricultural Economics 37: 523-551.

[10] Cupak, A., Pokrivcak, J., Rizov, M. (2016): Demand for food away from home in Slovakia. - Finance a úvěr - Czech Journal of Economics and Finance 66: 354-369.

[11] Drescher, L. S., Roosen, J. (2013): A cohort analysis of food at home and food away from home expenditures in Germany. - German Journal of Agricultural Economics 62: 39-51.

[12] Fabiosa, J. F. (2008): The food away from home consumption expenditure pattern in Egypt. https://lib.dr.iastate.edu/cgi/viewcontent.cgi?article=1495\&context=card_workingpapers.

[13] Fanning, J., Marsh, T., Stiegert, K. (2010): Determinants of US fast food consumption 1994-1998. - British Food Journal 112: 5-20.

[14] Gül, A., Akbay, C., Özcicek, C., Özel, R., Özdes Akbay, A. (2007): Expenditure pattern for food away from home consumption in Turkey. - Journal of International Food \& Agribusiness Marketing 19: 31-43.

[15] Ham, S., Hwang, J. H., Kim, W. G. (2004): Household profiles affecting food-away-from home expenditures: a comparison of Korean and US households. - Hospitality Management 23: 363-379.

[16] Heckman, J. J. (1979): Sample selection bias as a specification error. - Econometrica 47: 153-161.

[17] Heng, H. L. S., Guan, A. T. K. (2007): Examining Malaysian household expenditure patterns on food-away-from-home. - Asian Journal of Agriculture and Development 4: 11-24. 
[18] Jang, S., Ha. S., Hong, G. S. (2007): Food away from home expenditure of senior households in the United States: a double-hurdle approach. - Journal of Hospitality \& Tourism Research 31: 147-167.

[19] Jensen, H. H., Yen, S. T. (1996): Food expenditures away from home bye type of meal. Canadian Journal of Agricultural Economics 44: 67-80.

[20] Keelan, C. D., Henchion, M. M., Newman, C. F. (2009): A double-hurdle model of Irish households' food service expenditure patterns. - Journal of International Food \& Agribusiness Marketing 21: 269-285.

[21] Langellier, B. A. (2015): Consumption and expenditure on food prepared away from home among Mexican adults in 2006. - Salud Publica Mex 57: 4-13.

[22] Leschewski, A. M., Weatherspoon, D. D., Kuhns, A. (2018): Household acquisition of healthy food away from home. - British Food Journal 120: 588-60.

[23] Liu, A., Niyongira, R. (2017): Chinese consumers' food purchasing behaviors and awareness of food safety. - Food Control 79: 185-191.

[24] Liu, H., Wahl, T. I., Seale, J. L., Bai, J. (2015): Household composition, income and food-away-from-home expenditure in Urban China. - Food Policy 51: 97-103.

[25] Liu, M., Kasteridis, P., Yen, S. T. (2013): Breakfast, lunch, and dinner expenditures away from home in the United States. - Food Policy 38: 156-164.

[26] Ma, H., Huang, J., Fuller, F., Rozelle, S. (2006): Getting rich and eating out: consumption of food away from home in Urban China. - Canadian Journal of Agricultural Economics 54: 101-119.

[27] Mancino, L., Todd, J., Lin, B. H. (2009): Separating what we eat from where: measuring the effect of food away from home on diet quality. - Food Policy 34: 557-562.

[28] Mihalopoulos, V. G., Demoussis, M. P. (2001): Greek household consumption of food away from home: A micro econometric approach. - European Review of Agricultural Economics 28: 421-432.

[29] Min, I., Fang, C., Li, Q. (2004): Investigation of patterns in food-away-from-home expenditure for China. - China Economic Review 15: 457-476.

[30] Mottaleb, K. A., Rahut, D. B., Mishra, A. K. (2017): Consumption of food away from home in Bangladesh: Do rich households spend more? Appetite 119: 54-63.

[31] Mutlu, S., Gracia, A. (2006): Spanish food expenditure away from home (HAFH): By type of meal. - Applied Economics 38: 1037-1047.

[32] Nayga, R. M. (1995): Presence of children and household food expenditures at home and away from home. - Journal of Consumer Studies \& Home Economics 19: 235-245.

[33] Nayga, R. M., Capps, O. (1992): Analysis of food away from home and food at home consumption: A systems approach. - Journal of Food Distribution Research 23: 1-10.

[34] Niyonzima, E., Ongol, M. P., Brostaux, Y., Koulagenko, N. K., Daube, G., Kimonyo, A., Sindic, M. (2017): Consumption patterns, bacteriological quality and risk factors for Salmonella contamination in meat-based meals consumed outside the home in Kigali, Rwanda. - Food Control 73: 546-554.

[35] Onurlubaş, E., Doğan, H. G., Gürler, A. Z. (2015): Consumer trends and case of food consumption away home in Turkey. - The Journal of International Social Research 38: 917-924.

[36] Piekut, M. (2016): Restaurants and hotels expenditure in Polish households of the elderly. - Economics and Management 8: 80-90.

[37] Rezende, D. C., Avelar, A. E. S. (2012): Factors that influence the consumption of food outside the home in Brazil. - International Journal of Consumer Studies 36(3): 300-306.

[38] Robson, S. M., Crosby, L. E., Stark, L. J. (2016): Eating dinner away from home: Perspectives of middle-to high-income parents. - Appetite 96: 147-153.

[39] Stewart, H., Yen, S. T. (2004): Changing household characteristics and the away-from home food market: A censored equation system approach. - Food Policy 29: 643-658.

[40] Stewart, H., Blisard, S., Bhuyan, S. Nayga, R. M. (2004): The demand for food away from home full service or fast food? - Agricultural Economic Report No. 829, USA. 
[41] Traş, M. F., Şengül, S. (2017): Cohort effect on food away from home in Turkey: A double hurdle approach. - Akdeniz University Journal of Economics and Administrative Sciences 17: 59-80.

[42] TURKSTAT (2018): Distribution of household consumption expenditures 2002-2016. http://www.tuik.gov.tr/PreTablo.do?alt_id=1012. Accessed 18 January 2018.

[43] USDA (2018): United States Department of Agriculture. https://www.ers.usda.gov/data-products/food-expenditures.aspx. Accessed 28 May 2018.

[44] Uzunöz, M., Akcay, Y., Aslan, C. (2011): Factors affecting consumer preferences of food away from home in Tokat Province of Turkey. - Bulgarian Journal of Agricultural Science 17: 597-605.

[45] Yen, S. T. (1993): Working wives and food away from home: the box-cox double hurdle model. - American Journal of Agricultural Economics 75: 884-895.

[46] Zan, H., Fan, J. X. (2010): Cohort effects of household expenditures on food away from home. - The Journal of Consumer Affairs 44: 213-233.

\section{APPENDIX}

Table A1. Heckman sample selection model both with maximum likelihood (MLE) and marginal impact estimates

\begin{tabular}{|c|c|c|c|c|c|c|c|c|c|c|}
\hline \multirow{3}{*}{ Variables } & \multicolumn{4}{|c|}{ MLE estimates } & \multicolumn{6}{|c|}{ Marginal effects } \\
\hline & \multicolumn{2}{|c|}{ Probability } & \multicolumn{2}{|c|}{ Level } & \multicolumn{2}{|c|}{ Probability } & \multicolumn{2}{|c|}{ Conditional } & \multicolumn{2}{|c|}{ Unconditional } \\
\hline & Parameter & t-value & Parameter & t-value & Parameter & t-value & Parameter & t-value & Parameter & t-value \\
\hline Constant & $-0.221^{*}$ & \begin{tabular}{|l|}
-1.661 \\
\end{tabular} & $215.201^{* * *}$ & 9.450 & & & & & & \\
\hline Male & $0.346^{* * *}$ & 5.476 & -2.965 & -0.267 & $9.790^{* * *}$ & 4.980 & 15.371 & 1.479 & $32.973^{* * *}$ & 3.737 \\
\hline Age $30-50$ & -0.067 & -0.954 & $-27.485^{* * *}$ & -2.905 & -1.696 & -0.952 & $-30.720^{* * *}$ & -3.304 & $-29.141^{* * *}$ & -3.218 \\
\hline Age $>50$ & $-0.392^{* * *}$ & -5.164 & -11.463 & -1.037 & $-10.049^{* * *}$ & -5.104 & $-30.606^{* * *}$ & -2.838 & $-46.905^{* * *}$ & -4.607 \\
\hline Married & $-0.199^{* * *}$ & -3.295 & $-26.184^{* * *}$ & -2.592 & $-4.733^{* * *}$ & -3.532 & $-35.336^{* * *}$ & -3.669 & $-40.740^{* * * *}$ & -4.648 \\
\hline Employed & $0.341^{* * *}$ & 8.230 & $55.888^{* * *}$ & 7.308 & $9.096^{* * *}$ & 7.912 & $73.090^{* * *}$ & 10.117 & $78.014^{* * *}$ & 12.713 \\
\hline Manager & $-0.183^{* *}$ & -2.387 & 9.372 & 0.987 & $-5.00^{* *}$ & -2.229 & -0.043 & -0.005 & -10.944 & -1.134 \\
\hline $\begin{array}{l}\text { Compulsory } \\
\text { insurance }\end{array}$ & $0.202^{* * *}$ & 4.529 & $29.880^{* * *}$ & 3.291 & $5.443^{* * * *}$ & 4.273 & $40.150^{* * *}$ & 4.678 & $43.671^{* * *}$ & 6.180 \\
\hline Retired & 0.051 & 1.159 & $-54.394^{* * *}$ & -7.033 & 1.277 & 1.168 & $-51.953^{* * *}$ & -6.907 & $-40.556^{* * *}$ & -6.014 \\
\hline $\begin{array}{l}\text { Entrepreneurial } \\
\text { income }\end{array}$ & $-0.261^{* * *}$ & -6.884 & $-86.305^{* * *}$ & -14.198 & $-6.875^{* * *}$ & -6.697 & $-99.334^{* * * *}$ & -17.242 & $-95.024^{* * *}$ & -18.881 \\
\hline State cash aids & $-0.144^{* * *}$ & -3.954 & $-39.807^{* * *}$ & -5.610 & $-3.733^{* * *}$ & -3.857 & $-46.896^{* * * *}$ & -6.923 & $-46.343^{* * *}$ & -8.015 \\
\hline $\begin{array}{l}\text { State in-kind } \\
\text { aids }\end{array}$ & -0.050 & -1.071 & 7.799 & 0.765 & -1.301 & -1.051 & 5.324 & 0.550 & 1.523 & 0.187 \\
\hline $\begin{array}{l}\text { Private cash } \\
\text { aids }\end{array}$ & 0.060 & 1.248 & $-24.532^{* * *}$ & -2.776 & 1.497 & 1.276 & $-21.662^{* *}$ & -2.534 & $-14.945^{* *}$ & -1.971 \\
\hline $\begin{array}{c}\text { Private in-kind } \\
\text { aids }\end{array}$ & 0.007 & 0.135 & -5.876 & -0.569 & 0.181 & 0.135 & -5.531 & -.0559 & -4.203 & -0.490 \\
\hline Foreign income & 0.010 & 0.118 & -17.252 & -1.072 & 0.260 & 0.119 & -16.755 & -1.089 & -13.377 & -0.999 \\
\hline Apartment & $-0.111^{* *}$ & -2.463 & $-13.794^{* *}$ & -2.052 & $-2.803^{* *}$ & -2.462 & $-19.142^{* * * *}$ & -2.969 & $-21.982^{* * *}$ & -3.666 \\
\hline Renter & $0.095^{*}$ & 1.680 & $19.611^{* *}$ & 2.231 & $2.350^{*}$ & 1.721 & $24.118^{* * *}$ & 2.839 & $25.439^{* * *}$ & 3.210 \\
\hline Homeowner & $-0.137^{* * *}$ & -2.657 & 4.682 & 0.577 & $-3.400^{* * *}$ & -2.708 & $-1.829^{* * *}$ & -0.234 & -8.948 & -1.244 \\
\hline Combi & 0.012 & 0.233 & 2.819 & 0.390 & 0.313 & 0.234 & 3.416 & 0.486 & 3.521 & 0.516 \\
\hline Stove & 0.071 & 1.213 & -0.845 & -0.101 & 1.794 & 1.209 & 2.577 & 0.324 & 6.047 & 0.815 \\
\hline Internet & $0.219^{* * *}$ & 5.509 & $20.924^{* * *}$ & 3.560 & $5.366^{* * *}$ & 5.718 & $31.230^{* * *}$ & 5.589 & $38.072^{* * *}$ & 7.218 \\
\hline One child & $0.254^{* * *}$ & 5.615 & 8.590 & 1.203 & $5.954^{* * *}$ & 6.116 & $20.127^{* * *}$ & 2.914 & $30.386^{* * *}$ & 4.713 \\
\hline Two child & $0.175^{* * *}$ & 3.712 & -4.280 & -0.595 & $4.211^{* * * *}$ & 3.917 & 3.840 & 0.557 & $12.466^{*}$ & 1.956 \\
\hline $\begin{array}{c}\text { Three and more } \\
\text { child }\end{array}$ & 0.049 & 0.954 & $-16.169^{*}$ & -1.921 & 1.225 & 0.970 & $-13.823^{*}$ & -1.720 & -8.919 & -1.237 \\
\hline $\begin{array}{l}\text { House feature } \\
\text { index }\end{array}$ & $-0.018^{*}$ & -1.697 & 0.118 & 0.0733 & $-0.446^{*}$ & -1.693 & -0.733 & -0.466 & -1.581 & -1.031 \\
\hline
\end{tabular}




\begin{tabular}{|c|c|c|c|c|c|c|c|c|c|c|}
\hline $\begin{array}{l}\text { Number of } \\
\text { autos }\end{array}$ & 0.019 & 0.555 & $-15.215^{* * *}$ & -2.793 & 0.469 & 0.555 & $-14.320^{* * *}$ & -2.745 & $-10.866^{* *}$ & -2.302 \\
\hline Primary school & $0.185^{* * *}$ & 4.115 & & & $4.638^{* * * *}$ & 4.135 & $8.868^{* * *}$ & 4.020 & $17.506^{* * * *}$ & 4.112 \\
\hline $\begin{array}{c}\text { Secondary } \\
\text { school }\end{array}$ & $0.131^{* *}$ & 2.178 & & & $3.152^{* *}$ & 2.285 & $6.074^{* *}$ & 2.240 & $12.059^{* *}$ & 2.246 \\
\hline High school & $0.289^{* * *}$ & 4.534 & & & $6.643^{* * *}$ & 5.025 & $12.925^{* * *}$ & 4.753 & $25.764^{* * *}$ & 4.855 \\
\hline College school & $0.228^{* * *}$ & 3.112 & & & $5.329^{* * *}$ & 3.397 & $10.336^{* * *}$ & 3.280 & $20.583^{* * *}$ & 3.300 \\
\hline $\begin{array}{l}\text { Number of } \\
\text { properties }\end{array}$ & $-0.046^{* * *}$ & -3.181 & & & $-1.155^{* * *}$ & -3.176 & $-2.205^{* * *}$ & -3.154 & $-4.350^{* * *}$ & 3.009 \\
\hline Children 0-5 & $-0.110^{* * *}$ & -4504 & & & $-2.790^{* * *}$ & -4.492 & $-5.324^{* * * *}$ & -4.415 & $-10.505^{* * *}$ & -4.399 \\
\hline Children 6-14 & $-0.088^{* * *}$ & -5.022 & & & $-2.235^{* * *}$ & -5.019 & $-4.266^{* * *}$ & -4.948 & $-8.417^{* * *}$ & -4.852 \\
\hline Children $15-18$ & 0.013 & 0.443 & & & 0.332 & 0.443 & 0.633 & 0.442 & 1.249 & 0.436 \\
\hline Adult $19+$ & $0.081^{* * *}$ & 6.102 & & & $2.059^{* *}$ & 6.057 & $3.929^{* * *}$ & 5.685 & $7.752^{* * *}$ & 5.839 \\
\hline $\begin{array}{c}\text { Total } \\
\text { expenditures }\end{array}$ & $0.273^{* * *}$ & 34.493 & & & $6.908^{* * *}$ & 30.998 & $13.183^{* * *}$ & 17.034 & $26.009^{* * *}$ & 23.503 \\
\hline Education & & & $-4.686^{* * *}$ & -6.835 & & & $-4.686^{* * *}$ & -4.903 & $-3.888^{* * *}$ & 3.762 \\
\hline Household size & & & $14.972^{* * * *}$ & 9.799 & & & $14.972^{* * *}$ & 9.577 & $12.423^{* * *}$ & 9.391 \\
\hline Income 2 & & & $74.116^{* * *}$ & 10.226 & & & $74.116^{* * *}$ & 10.226 & $61.497^{* * *}$ & 10.210 \\
\hline Income 3 & & & $202.437^{* * *}$ & 20.766 & & & $202.420^{* * * *}$ & 20.765 & $167.956^{* * *}$ & 20.614 \\
\hline$\sigma$ & & & $228.437^{* * *}$ & 104.540 & & & & & & \\
\hline$\rho$ & & & $-0.551^{* * *}$ & -22.167 & & & & & & \\
\hline \multicolumn{2}{|c|}{ Log-likelihood value } & \multicolumn{3}{|c|}{-64110.05} & & & & & & \\
\hline
\end{tabular}

Statistical significance $* * *$ at the $1 \%$ level; ** at the $5 \%$ level; * at the $10 \%$ level

Table A2. Double hurdle model both with maximum likelihood estimates (MLE) and marginal impact estimates

\begin{tabular}{|c|c|c|c|c|c|c|c|c|c|c|}
\hline \multirow{3}{*}{ Variables } & \multicolumn{4}{|c|}{ MLE estimates } & \multicolumn{6}{|c|}{ Marginal effects } \\
\hline & \multicolumn{2}{|c|}{ Probability } & \multicolumn{2}{|c|}{\begin{tabular}{|r|} 
Level \\
\end{tabular}} & \multicolumn{2}{|c|}{ Probability } & \multicolumn{2}{|c|}{ Conditional } & \multicolumn{2}{|c|}{ Unconditional } \\
\hline & Parameter & t-value & Parameter & t-value & Parameter & t-value & Parameter & t-value & Parameter & t-value \\
\hline Constant & \begin{tabular}{|l|}
-0.374 \\
\end{tabular} & -0.782 & $48.099^{* *}$ & 2.027 & & & & & & \\
\hline Male & $0.566^{* * *}$ & 3.950 & $28.305^{* *}$ & 2.355 & $3.884^{* *}$ & 2.303 & $14.693^{* *}$ & 2.437 & $20.699^{* *}$ & 2.422 \\
\hline Age $30-50$ & -0.130 & -0.562 & $-29.081^{* * *}$ & -2.795 & $-3.891^{* * *}$ & 2.787 & $-15.315^{* * *}$ & -2.808 & $-21.539^{* * * *}$ & -2.806 \\
\hline Age $>50$ & $-0.549^{* * *}$ & -2.163 & $-42.829^{* * * *}$ & -3.599 & $-5.734^{* * *}$ & -3.590 & $-22.581^{* * * *}$ & -3.624 & $-31.736^{* * *}$ & -3.622 \\
\hline Married & -0.216 & -1.487 & $-40.553^{* * *}$ & -3.643 & $-5.205^{* * *}$ & -3.788 & $-22.064^{* * * *}$ & -3.543 & $-30.819^{* * *}$ & -3.568 \\
\hline Employed & 0.011 & 0.088 & $84.973^{* * *}$ & 10.857 & $11.712^{* * * *}$ & 10.470 & $43.494^{* * *}$ & 11.211 & $61.352^{* * *}$ & 11.210 \\
\hline Manager & 0.327 & 0.317 & -5.029 & -0.484 & -0.674 & -0.480 & -2.630 & -0.484 & -3.706 & -0.484 \\
\hline $\begin{array}{l}\text { Compulsory } \\
\text { insurance }\end{array}$ & -0.029 & -0.218 & $55.831^{* * *}$ & 5.811 & $7.800^{* * * *}$ & 5.562 & $28.250^{* * *}$ & 6.078 & $39.962^{* * *}$ & 6.052 \\
\hline Retired & $-0.241^{*}$ & -1.741 & $-34.611^{* * *}$ & -4.268 & $-4.692^{* * *}$ & -4.199 & $-18.037^{* * * *}$ & -4.340 & $-25.410^{* * *}$ & -4.329 \\
\hline $\begin{array}{l}\text { Entrepreneurial } \\
\text { income }\end{array}$ & 0.217 & 1.618 & $-108.756^{* * *}$ & -17.095 & $-15.077^{* * *}$ & -16.361 & $-55.261^{* * *}$ & -17.603 & $-77.935^{* * *}$ & -17.678 \\
\hline State cash aids & $0.211^{*}$ & 1.811 & $-58.331^{* * *}$ & -7.814 & $-8.000^{* * *}$ & -7.570 & $-30.014^{* * *}$ & -8.026 & $-42.352^{* * *}$ & -8.010 \\
\hline $\begin{array}{l}\text { State in-kind } \\
\text { aids }\end{array}$ & 0.129 & 0.935 & -6.801 & -0.637 & -0.913 & -0.632 & -3.562 & -0.640 & -5.017 & -0.639 \\
\hline Private cash aids & -0.114 & -0.842 & -6.223 & -0.651 & -0.836 & -0.648 & -3.276 & -0.657 & -4.608 & -0.656 \\
\hline $\begin{array}{l}\text { Private in-kind } \\
\text { aids }\end{array}$ & $0.311^{* *}$ & 2.059 & -9.562 & -0.856 & -1.287 & -0.847 & -4.992 & -0.862 & -7.036 & -0.861 \\
\hline Foreign income & $11.503^{* * *}$ & 3.169 & $-40.803^{* *}$ & -2.434 & $-5.709^{* *}$ & -2.332 & $-20.606^{* *}$ & -2.542 & $-29.174^{* *}$ & -2.530 \\
\hline Apartment & 0.098 & 0.723 & $-22.648^{* * * *}$ & -3.119 & $-3.021^{* * *}$ & -3.114 & $-11.944^{* * *}$ & -3.123 & $-16.797^{* * *}$ & -3.123 \\
\hline Renter & $0.349^{* *}$ & 2.048 & $19.427^{* *}$ & 2.004 & $2.555^{* *}$ & 2.033 & $10.389^{* *}$ & 1.986 & $14.568^{* *}$ & 1.990 \\
\hline Homeowner & $0.254^{*}$ & 1.689 & $-21.971^{* *}$ & -2.471 & $-2.905^{* *}$ & -2.492 & $-11.654^{* *}$ & -2.453 & $-16.372^{* *}$ & -2.457 \\
\hline Combi & $-0.576^{* * *}$ & -2.852 & $16.769^{* *}$ & 2.145 & $2.212^{* *}$ & 2.162 & $8.850^{* * *}$ & 2.122 & $12.450^{* *}$ & 2.128 \\
\hline Stove & -0.302 & -1.411 & $18.962^{* *}$ & 2.078 & $2.53^{3 * *}$ & 2.074 & $9.971^{* * *}$ & 2.080 & $14.032^{* *}$ & 2.080 \\
\hline Internet & $-0.444^{* * *}$ & -3.067 & $50.534^{* * *}$ & 8.105 & $6.590^{* * *}$ & 8.230 & $27.091^{* * *}$ & 7.973 & $37.953^{* * *}$ & 8.015 \\
\hline One child & -0.133 & -0.939 & $36.789^{* * * *}$ & 4.773 & $4.753^{* * * *}$ & 4.924 & $19.895^{* * *}$ & 4.664 & $27.829^{* * * *}$ & 4.692 \\
\hline Two child & -0.179 & -1.056 & $20.551^{* * * *}$ & 2.667 & $2.693^{* * * *}$ & 2.715 & $10.984^{* * * *}$ & 2.632 & $15.407^{* * * *}$ & 2.640 \\
\hline
\end{tabular}




\begin{tabular}{|c|c|c|c|c|c|c|c|c|c|c|}
\hline $\begin{array}{l}\text { Three and more } \\
\text { child }\end{array}$ & 0.115 & 0.597 & -6.870 & -0.775 & -0.922 & -0.770 & -3.600 & -0.779 & -5.070 & -0.778 \\
\hline $\begin{array}{l}\text { House feature } \\
\text { index }\end{array}$ & $-0.105^{* * *}$ & -3.346 & 1.226 & 0.695 & 0.163 & 0.340 & 0.641 & 0.590 & 0.904 & 0.690 \\
\hline Number of autos & -0.022 & -0.192 & -7.504 & -1.285 & -1.002 & -1.285 & -3.959 & 1.287 & -5.567 & 1.286 \\
\hline Primary school & $0.253^{* *}$ & 2.436 & & & 0.001 & 0.925 & 0.015 & 0.994 & 0.015 & 0.974 \\
\hline $\begin{array}{l}\text { Secondary } \\
\text { school }\end{array}$ & $0.373^{* *}$ & 2.085 & & & 0.001 & 0.953 & 0.014 & 1.025 & 0.014 & 1.004 \\
\hline High school & 0.225 & 1.035 & & & 0.001 & 0.796 & 0.010 & 0.836 & 0.010 & 0.825 \\
\hline College school & -0.012 & -0.045 & & & 0.000 & 0.044 & -0.001 & -0.044 & -0.001 & -0.044 \\
\hline $\begin{array}{l}\text { Number of } \\
\text { properties }\end{array}$ & $-0.146^{* * *}$ & -2.650 & & & -0.001 & -0.044 & -0.009 & -0.009 & -0.009 & -0.012 \\
\hline Children 0-5 & -0.079 & -0.799 & & & 0.000 & 0.003 & -0.005 & -0.006 & -0.005 & -0.006 \\
\hline Children 6-14 & $-0.197^{* * *}$ & -3.198 & & & -0.001 & -0.008 & -0.012 & -0.020 & -0.012 & -0.016 \\
\hline Children 15-18 & 0.097 & 0.768 & & & 0.001 & 0.004 & 0.006 & 0.018 & -0.006 & -0.007 \\
\hline Adult $19+$ & $0.175^{* * *}$ & 2.805 & & & 0.001 & 0.008 & 0.010 & 0.008 & 0.010 & 0.009 \\
\hline $\begin{array}{c}\text { Total } \\
\text { expenditures }\end{array}$ & $1.852^{* * *}$ & 13.728 & & & 0.011 & 0.058 & 0.110 & 0.166 & 0.110 & 0.120 \\
\hline Education & & & $-3.598^{* * *}$ & -4.853 & $-0.480^{*}$ & -1.672 & -1.899 & -1.579 & $-2.761^{* * *}$ & -2.896 \\
\hline Household size & & & $9.178^{* * *}$ & 5.476 & $1.224^{* * *}$ & 2.994 & $4.845^{* * *}$ & 4.723 & $6.812^{* * *}$ & 4.704 \\
\hline Income 2 & & & $102.321^{* * *}$ & 14.305 & $13.567^{* * *}$ & 13.897 & $54.127^{* * *}$ & 14.480 & $75.862^{* * *}$ & 14.549 \\
\hline Income 3 & & & $247.599^{* * *}$ & 24.818 & $24.101^{* * * *}$ & 31.178 & $157.816^{* * *}$ & 21.519 & $207.372^{* * *}$ & 23.213 \\
\hline$\sigma$ & & & $242.332^{* * *}$ & 165.359 & & & & & & \\
\hline$\rho$ & & & $-0.868^{* * *}$ & -37.169 & & & & & & \\
\hline \multicolumn{5}{|c|}{-61885.49} & & & & & & \\
\hline
\end{tabular}

Statistical significance $* * *$ at the $1 \%$ level; $* *$ at the $5 \%$ level; $*$ at the $10 \%$ level 